\title{
Eggshell calcification
}

\author{
Rushad D Patell, Rupal V Dosi, Harshal K Joshi, Purav C Shah
}

Department of Medicine, Medical College Baroda, Vadodara, India

\section{Correspondence to}

Dr Rushad Dhunrumi Patell, rushadpatell@gmail.com

\section{DESCRIPTION}

A 55-year-old man from Khambhat, India, who was admitted to undergo a planned repair of a direct inguinal hernia, was found to have bilateral hilar lymphadenopathy with calcification in a peculiar circumferential pattern identified as eggshell calcification on chest X-ray (figure 1) as part of a routine preoperative evaluation. The patient denied any symptoms of cough, dyspnoea, chest pain, night sweats or weight loss. Moreover, there was no contact history for tuberculosis. On further probing he admitted that he had in fact worked as a gemstone cutter for more than 20 years. A complete physical examination and laboratory work up (including serum ACE levels and an antinuclear antibody profile) were normal apart from the hernia. Pulmonary function tests were normal and a high resolution of the chest revealed, apart from the calcified lymph nodes, subtle reticulonodular opacities in the upper lobes. Based on his significant occupational history a diagnosis of silicosis was made and the patient was discharged on close follow-up after an uneventful surgery.

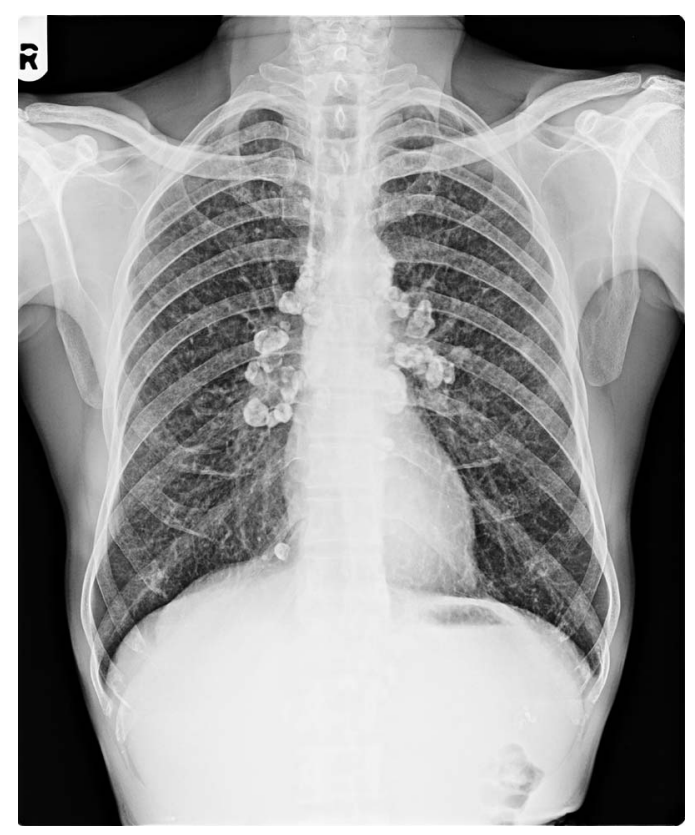

Figure 1 Plain X-ray posteroanterior view showing bilateral hilar adenopathy with eggshell calcification.
Silicosis refers to a spectrum of respiratory diseases caused by inhalation of silica dust, usually as an occupational hazard. ${ }^{1}$ The clinical presentation varies from an insidious chronic course, radiographic changes being seen sometimes up to a decade after cessation of exposure, to a more rapid, accelerated course, which is fortunately rare. Eggshell calcification is most commonly seen in occupational diseases, like silicosis and coalworker's pneumoconiosis as well as sarcoidosis but rarely in postirradiated Hodgkin's disease, blastomycosis, scleroderma, amyloid and histoplasmosis. ${ }^{2}$ Increased awareness of the toll on the health and lives of gem workers especially in regions like Khambhat in India is necessary to institute timely prevention and screening precautions. ${ }^{3}$

\section{Learning points}

Silicosis may present as an incidental radiological finding several years after exposure to silica dust.

- Egg shell calcification is a striking radiological finding that in conjunction with a conducive occupational history may lead to the appropriate diagnosis.

- Increased awareness and institution of appropriate preventive measures which are crucial to reducing incidence and morbidity in a susceptible population.

Contributors All authors have contributed to writing of manuscript as well as caring for the patient.

Competing interests None.

Patient consent Obtained.

Provenance and peer review Not commissioned; externally peer reviewed.

\section{REFERENCES}

1 Health effects of occupational exposure to respirable crystalline silica. Cincinnat: NIOSH, 2002. http://www.cdc.gov/niosh/docs/ 2002-129/pdfs/2002-129.pdf

2 Gross B, Schneider HJ, Proto A. Eggshell calcification of lymph nodes. Am J Roentgenol 1980;135:1265-8.

3 Patel J, Robbins M. The agate industry and silicosis in Khambhat, India. New Solut 2011;21:117-39. 
Copyright 2013 BMJ Publishing Group. All rights reserved. For permission to reuse any of this content visit http://group.bmj.com/group/rights-licensing/permissions.

BMJ Case Report Fellows may re-use this article for personal use and teaching without any further permission.

Become a Fellow of BMJ Case Reports today and you can:

- Submit as many cases as you like

- Enjoy fast sympathetic peer review and rapid publication of accepted articles

- Access all the published articles

- Re-use any of the published material for personal use and teaching without further permission

For information on Institutional Fellowships contact consortiasales@bmjgroup.com

Visit casereports.bmj.com for more articles like this and to become a Fellow 